Al-Amwal: Jurnal Ekonomi dan Perbankan Syariah

ISSN: 2303-1573 e-ISSN: 2527-3876

Homepage: https://www.syekhnurjati.ac.id/jurnal/index.php/amwal email: jurnalalamwal@syekhnurjati.ac.id

\title{
DETERMINANTS FACTORS TO FIRM VALUE ON MANUFACTURING COMPANY LISTED ON THE STOCK EXCHANGE INDONESA
}

\author{
Dikdik Harjadi \\ Universitas Kuningan, Indonesia \\ e-mail: dikdik.harjadi@uniku.ac.id \\ Jaelani \\ Universitas Kuningan, Indonesia \\ e-mail: jaelani@uniku.ac.id \\ Dewi Fatmasari \\ IAIN Sheikh Nurjati Cirebon, Indonesia \\ e-mail: dewifatmasari73@gmail.com
}

\begin{abstract}
The study aims to analyze the influence of determining factors to the firm value, the gap phenomenon that the increase in the stock price index of the manufacturing sector is only slightly compared to the IDX Composite. Whereas the manufacturing sector are expected to have strong financial performance in contributing to the economy. This research uses a quantitative approach, with purposive sampling, obtained a sample of 110the manufacturing companieslisted on the Indonesia Stock Exchange (IDX) in 2010 - 2017, using multiple linear regression. The results show that the dividend policy and profitability affect the firm value, while managerial ownership and board size are the opposite. This finding is interesting, the increase in the firm value of manufacturing sector is determined by dividend and profit policies, not manager incentives and monitoring of the board, because in general the company's the managers and board are held by the majority shareholder.
\end{abstract}

Keywords: firm value, dividend policy, managerial ownership, board size, and profitability. 


\begin{abstract}
Abstrak
Penelitian ini bertujuan untuk menganalisis pengaruh faktor-faktor penentu terhadap nilai perusahaan, fenomena gap dimana kenaikan indeks harga saham sektor manufaktur hanya sedikit dibandingkan dengan BEI. Padahal sektor manufaktur diharapkan memiliki kinerja keuangan yang kuat dalam memberikan kontribusi bagi perekonomian. Penelitian ini menggunakan pendekatan kuantitatif, dengan purposive sampling, diperoleh sampel sebanyak 110 perusahaan manufaktur yang terdaftar di Bursa Efek Indonesia (BEI) tahun 2010 - 2017 dengan menggunakan regresi linier berganda. Hasil penelitian menunjukkan bahwa kebijakan dividen dan profitabilitas berpengaruh terhadap nilai perusahaan, sedangkan kepemilikan manajerial dan ukuran dewan komisaris sebaliknya. Temuan ini menarik, kenaikan nilai perusahaan sektor manufaktur ditentukan oleh kebijakan dividen dan laba, bukan insentif manajer dan pengawasan dewan, karena pada umumnya pengurus dan dewan perusahaan dipegang oleh pemegang saham mayoritas.
\end{abstract}

Kata kunci: nilai perusahaan, kebijakan dividen, kepemilikan manajerial, ukuran dewan komisaris, dan profitabilitas.

\title{
INTRODUCTION
}

High the firm value is the expectation of shareholders, because high the firm value shows that the shareholders' prosperity is also high. Shareholders' wealth is presented by the market price of stock which is a reflection of investment decisions, funding, and asset management. Then the stock price is used as a proxy for the firm value, because the stock price is a value that is willing to be paid by prospective buyers (Suad, H., 2008). Shareholders are very important to pay attention to financial policies, so companies must consider every strategic decision related to the company's business activities because it will have an impact on improving the welfare of shareholders. This increase can be achieved if the company is able to provide a return on investment that is greater than the investment capital costs incurred. Therefore, company management must be able to manage company resources effectively and efficiently, so as to increase the firm value.

In maximizing the firm value there is an agency problem, because between the principal and the manager (agent) has different interests, shareholders (principals) tend to want sustainable and high profit and return on rapid investment, the shareholders demand the manager to get high profits, while the managers tend to try to maintain their positions and get high compensation for their performance, so managers will make every effort to get high profits even though they often use actions that cause a decrease in the firm value. Managers in making financial decisions have an impact on the firm value, so there is a need for monitoring efforts from shareholders, so that financial decisions by the managers that have a positive impact raise stock prices. Increasing stock prices, the higher the prosperity of shareholders, the rise and fall of stock prices in the capital market becomes an interesting issue for the company itself, including the companies of manufacturing sector.

The phenomenon of the ups and downs of the company's stock prices in the manufacturing sector can indicate the condition of the financial performance of the manufacturing sector in general. The following developments in stock prices in the 
stock exchange as indicated by the trend of the IDX Composite on the Indonesia Stock Exchange (IDX) can be seen in thetable below.

Table 1. Development of IDX Composite2010 - 2017

\begin{tabular}{|c|c|c|c|c|c|}
\hline \multirow[t]{2}{*}{ No } & \multirow[t]{2}{*}{ Year } & \multicolumn{2}{|c|}{ all issuers } & \multicolumn{2}{|c|}{$\begin{array}{c}\text { issuers of the } \\
\text { manufacturing sector }\end{array}$} \\
\hline & & $\begin{array}{l}\text { IDX Composite } \\
\text { (Rp) }\end{array}$ & $\wedge \%$ & $\begin{array}{l}\text { IDX Composite } \\
(\mathrm{Rp})\end{array}$ & $\wedge \%$ \\
\hline 1 & 2010 & 3703 & & 823 & \\
\hline 2 & 2011 & 3821 & $3,19 \%$ & 993 & $20,66 \%$ \\
\hline 3 & 2012 & 4316 & $12,95 \%$ & 1148 & $15,61 \%$ \\
\hline 4 & 2013 & 4274 & $-0,97 \%$ & 1205 & $4,97 \%$ \\
\hline 5 & 2014 & 5226 & $22,27 \%$ & 1352 & $12,20 \%$ \\
\hline 6 & 2015 & 4593 & $-12,11 \%$ & 1305 & $-3,48 \%$ \\
\hline 7 & 2016 & 5296 & $15,31 \%$ & 1445 & $10,73 \%$ \\
\hline 8 & 2017 & 6355 & $20,00 \%$ & 1541 & $6,64 \%$ \\
\hline \multicolumn{2}{|c|}{ avaraged } & 5.369 & $8,66 \%$ & 1.402 & $9,62 \%$ \\
\hline
\end{tabular}

Source: ICMD, 2018 (processed)

Based on the table above, it shows that the IDX Composite during 2010-2017 averaged $8.66 \%$ per year, while the average IDX Composite for the manufacturing sector in the same period increased by $9.62 \%$ or slightly above the IDX Composite, it appears that the IDX Composite for the manufacturing sector is relatively relatively the same, similar to the increase in the IDX Composite, this is a gap, because the companies in manufacturing sector should have strong financial performance, to make a large contribution to Indonesia's Gross Domestic Product (GDP). The phenomenon of not optimal increase in the IDX Composite for the manufacturing sector is the focus of this research

The purpose of this study is to analyze the influence of determinant factors on the firm value of the manufacturing sector, with the formulation of the problem: How is the influence of dividend policy, managerial ownership, board size, and profitability of the firm value in manufacturing sector listed on the IDX on 2010-2017?. This research is expected to contribute to the science of financial management, especially those related to firm value, and practical uses for investors, company management, and further research.

In the activity of increasing the firm value it can cause agency problems, namely the occurrence of a conflict of interest between the agent and the principal, according to Jensen, M. and Meckling, W. (1976) stated that agency relationship or agency relationship is a contract in which one or morepeople (principals) involve other people (agents) to perform certain services on behalf of principals and involve delegation of authority to agents for the best decision making for principals. Furthermore, according to Jensen, M. and Meckling, W. (1976), the relationship between principal and agent is a good reason to believe that the agent does not always act for the interests of the principal. Therefore, a supervisory action is needed or also called monitoring by the principal to limit deviant actions by agents or the managers, so that managers can carry out their duties in accordance with the principal's wishes.

Conflicts of interest have potential agency costs such as management decisions that do not maximize shareholder interests. In order to minimize agency issues, the 
shareholders/owner (principals) must bear the agency costs. Providing incentives in the form of managerial ownership can prevent conflicts of interest between the managers and owners and then increase the firm value, because managerial ownership can align the interests of managers (agents) with shareholders, so managers can have strong incentives to pursue behavior to maximize the firm value.

Agency costs have a link to dividend policy, more specifically dividend payments can be used to control company agency costs. Agency costs are known as hypothesis free cash flow Jensen, M.C., (1986). The managers have large free cash flows that tend to increase resources under their control and invest in low return projects but do not distribute to shareholders. The costs of monitoring and controlling expensive agents as agents can be involved in decision-making and behavior that may be inconsistent with maximizing shareholder wealth, even creating information asymmetry that allows agents to carry out activities that can threaten the company's performance and ultimately endanger the welfare of the owner.

The board is considered an intermediary entity between the owner and manager whose members are chosen by the principal to monitor and limit the freedom of the agent's decision. The board is effective as a supervisor of the process of maximizing the firm value. Thus based on the description above this research focuses on agency theory to explain possible company conflicts and their impact on increasing the firm value through dividend policy, managerial ownership, board size and profit maximization.

The firm value

The firm value is the price that is willing to be paid by prospective buyers if the firm is sold. The firm value is also defined as market value because the the firm value can provide maximum shareholder prosperity, if the company's stock price increases (Hasnawati, S., 2005). So from that sense the firm value is measured using the stock price. The firm value shows the value of various assets owned by the company, including the securities issued. The firm value of a company go public other than showing the value of all assets, is also reflected in the market value or stock price, so that the higher the stock price reflects the high the firm value. Stock prices are an indicator of the manager's success in managing company assets, while the firm value of a company go public is determined by the stock market price. Normatively the purpose of corporate financial management is to increase the firm value, which is reflected in the stock market price (Fama, E. F, 1978; Wright, P., and Ferris, S.P., 1997).

In assessing the firm value there are many techniques developed. The firm value there are two concept approaches, namely the book value approach and market value. If the book value is the price recorded in the company's stock value, that is price to book value in the predetermined period. While the market value is the stock price that occurs on certain stock markets by the demand and supply of the stock by market participants. The firm value is the value given by the stock market to company management. Research using market prices such as Fama, E.F, (1978) in his research using the concept of market value concepts to measure the firm value.

\section{LITERATURE REVIEW}

Relationship between dividend policy and the firm value

Companies that have high quality will usually pay higher dividends, dividend payments themselves are often followed by an increase in stock prices and a decrease in dividend payments will be followed by a decrease in stock prices. With the increase in stock prices can increase the firm value. The use of dividends as a sign of an 
announcement stating that a company has decided to increase dividends per share may be interpreted by investors as a good signal, because higher dividends per share indicate that the company believes future cash flows will be large enough to bear the level high dividends (Weston, FJ, and Copeland, TE, (1995).

The studies that have been done in general result in dividend policy affecting the firm value. Yudana, I.K., and Wati, NWAE., (2011), managerial ownership has a significant positive effect on the firm value, dividend policy has a significant positive effect on the firm value. But Hardiningsih's research, (2009), dividend policy insignificant affect the firm value.

Relationship between managerial ownership and firm value

Managerial ownership is a condition where the manager has a stock, meaning the manager as well as the shareholder of the company. According to Christiawan, Y. J., and Tarigan, J., (2007), the existence of managerial ownership becomes an interesting thing if it is associated with the agency theory. Agency conflicts can be reduced, if the manager has a company share. Managerial ownership, managers try to increase the firm value, because it will increase their wealth as shareholders. Managerial ownership can align management's interests with shareholders, because the managers can directly feel the benefits of decisions taken and also bear the loss as a consequence of wrong decisions.

The studies that have been carried out have generally resulted in management ownership affecting the the firm value. The research of Taswan and Soliha, E., (2002), found a significant and positive relationship between management ownership and firm value. Research by Rizqia, et al., (2013), managerial ownership has a positive effect on firm value. In contrast to the research results of Sukirni, D., (2012), managerial ownership has a significant negative effect on firm value, and Hardiningsih, (2009), managerial ownership, dividend policy insignificant affect the firm value.

Relationship between the board size and the firm value

The role of the board can increase the firm value by limiting the level of earnings management through the monitoring function of the financial statements. The function of the board of commissioners is in accordance with the National Committee on Governance Policy (KNKG, 2006), that the board size is responsible and authorized to oversee management actions, and provide advice to management if deemed necessary by the board size. According to Beiner, S., et.al., (2003) that the board size is the number of members of the company's board. Research by Mai, M.U., (2011), board size has a positive and significant effect on Tobin's q. But research conducted by Yermack, D., (1996), concluded that a small board size would be more effective in carrying out supervisory actions than a large the board size.

Relationship between profitability and firm value

Profitability is the company's ability to make a profit in relation to sales, total assets and own capital (Sartono, RA, (2000). Thus, for long-term investors will be very interested in profitability analysis, because it can provide supporting evidence about the company's ability to make a profit. and the extent of the effectiveness of company management (Smith, M., and Skousen, K., 1992).

Research that has been done results in general profitability affects the value of the company, research conducted by Haryuningputri, M. and Widyarti, ET., (2012), that the variables ROA, ROS, and EVA have insignificant effect on stock prices, while research by Rizqia, et al., (2013), profitability has a positive effect on firm value.

Conceptual framework 
Based on the results of the discussion above, then to illustrate the influence of the independent variables on the firm value, the following Conceptual framework is compiled.

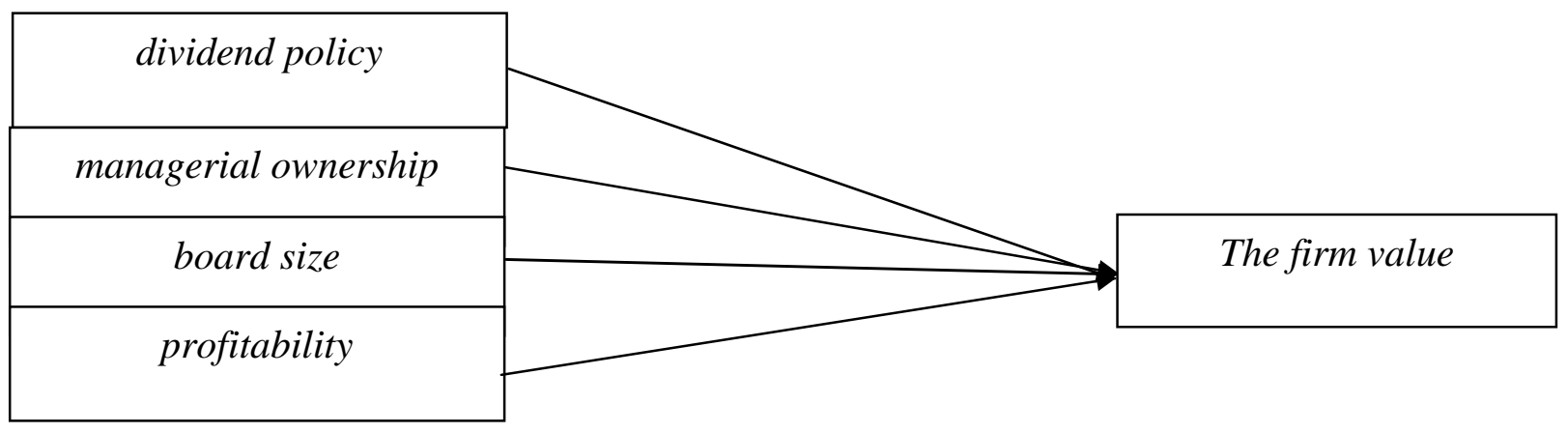

Figure 1. Conceptual Framework

Based on the background, literature review, and Conceptual framework described above, the following hypotheses can be prepared:

Hypothesis 1: Dividend policy affects the firm value

Hypothesis 2: Managerial ownership affects the firm value

Hypothesis 3: The Board size affects the firm value

Hypothesis4: Profitability affects the firm value

\section{METHOD}

The population in this study are all manufacturing sector companies listed on the Indonesia Stock Exchange (IDX), with observation periods ranging from 2010 to 2017. The sampling method used is manufacturing companies listed on the IDX, with the following criteria :1) Manufacturing sector companies that are registered and remain active on the IDX until 2017, so that developments in profitability, dividends and share ownership can be identified; and 2) The company owns and publishes financial statements as of December 31 for the financial year 2010 up to the financial year 2017;

Based on the explanation above, the sample in this study is 110 companies of manufacturing sector listed on the IDX, during the observation period from 2010 2017. After the steps of collecting data by accessing the ICMD website: http://www.idx.co.id, followed by a documentation study of the data that has been collected to obtain information about the observation unit. Then the next step identifies the research variables, which consist of: dividend policy, managerial ownership, board size, and profitability.

Data analysis techniques are used to find out and obtain an overview of the effect of dividend policy, managerial ownership, size board, and profitability on the firm value of companies of manufacturing sector on the Indonesia Stock Exchange (IDX) 2010-2017, using the data panel model. Data analysis using regression analysis and examined classic assumptions:normality test, multicollonierity test, autocorrelation test and heteroscedasticity test. Multiple regression analysis testing uses the regression equation as follows:

$\mathrm{Y}=\alpha+\mathrm{b} 1 \mathrm{X} 1+\mathrm{b} 2 \mathrm{X} 2+\mathrm{b} 3 \mathrm{X} 3+\mathrm{b} 4 \mathrm{X} 4+\varepsilon \mathrm{i}$

Notes :

$\mathrm{Y} \quad=$ the firm value

$\alpha \quad=$ regression constant is the value of $\mathrm{Y}$ if $\mathrm{X}=0$ 
b1-b4 $=$ the regression coefficient is to state the change in the value of $\mathrm{Y}$ when it occurs change in $\mathrm{X}$ value

$\mathrm{X} 1-\mathrm{X} 4$ = dividend policy, managerial ownership, board size, and profitability

घi $=$ error term, which is the error of the estimator in the study

\section{RESULTS AND DISCUSSION}

Results to examine classic assumptions:

1) Normality Test

Based on the results of the second stage of the test by improving the normality of the data of the first stage of the test results with the transformation of logarithms $(\log )$ on the variables $Y, X 3$ and $X 4$ to $\log Y, \log X 3$ and $\log X 4$, while the variables $\mathrm{X} 1$ and $\mathrm{X} 2$ are dummy variables. The results of the second phase test are still not normally distributed because of probability of 0.000062 smaller than 0.05 and Jarque Bera's value of 19,368 is still greater than 2.0. However, this result is close to normal distribution.

2) Multicollinearity Test

Multicollinearity test results, that the results of the correlation between variables $\mathrm{X} 1, \mathrm{X} 2, \mathrm{X} 3$, and $\mathrm{X} 4$ are not greater than 0.90 . This shows that the variables are assumed to have no linear relationship between the four variables.

3) Heteroscedasticity Test

Glejser test is used, that the output results can be seen the probability values of variables $\mathrm{X} 1, \mathrm{X} 2, \mathrm{X} 3$, and $\mathrm{X} 4$ greater than 0.05 so that the data is inferred to be homokedasticity.

4) Autocorrelation Test

The Durbin-Watson test (DW Test) is used, with the output of the DW value being 1,901. This value is compared to the DW table value, the value of DW (d) $=$ 1,901 , then $1,810<1,901<2,190$ (du $<\mathrm{d}<4-\mathrm{du}$ ). So it can be concluded that the null hypothesis that there is no positive and negative autocorrelation is accepted, so that the regression model used is correct in linear form.

Hypothesis Testing

Tests to explain the influence of variable Dividend Policy, Managerial Ownership, Board Size, and Profitability on the firm value, were to examine fixed effect. Furthermore, to find out whether the fixed effect model is different or indifferent, a Chow-test or Likelihood ratio test is tested or model testing. The test results of Chow test or F statistics test shows the probability value of $\mathrm{F}$ test is 0.0000 and the probability value of Chi-square is 0.0000 . Chi square probability smaller than $0.05(<5 \%)$ is stated as significant so that $\mathrm{H} 0$ is rejected and $\mathrm{H} 1$ is accepted, then the model follows the fixed effect model (FEM), so it is continued by estimating the random effect model (REM). To find out the model that is more in accordance with the REM or the FEM, the test is continued using the Hausman test. Then with the Hausmann Test, the test results of the probability of period random effect of 0.0000 are declared not significant (p-value smaller than 5\%), so that $\mathrm{H} 0$ is rejected and $\mathrm{H} 1$ is accepted. Therefore, the appropriate model follows the FEM, then the regression equation can be made as follows:

LOGY $=5.6319+0.23001 * \mathrm{X} 1+0.0084 * \mathrm{LOGX} 2-0.3198 * \mathrm{LNX} 3+0.1396 * \mathrm{LNX} 4$

1)

The results of regression analysis with the FEM equation model approach it can be seen that the test of the coefficient of determination (R2) with a R2 value of 0.7345 
shows that the seven independent variables $\mathrm{X} 1, \mathrm{X} 2, \mathrm{X} 3$, and $\mathrm{X} 4$ are able to explain the effect on variable $\mathrm{Y}$ by $73.45 \%$, while the remaining $26.55 \%$ is explained by other variables.

The summary of the results of testing the hypothesis above which explains the influence between variables in this research model can be seen in the following table:

Table 2. Hypothesis Testing Results

\begin{tabular}{lcccccc}
\hline $\begin{array}{c}\text { the } \\
\text { hypothesis }\end{array}$ & $\begin{array}{c}\text { the } \\
\text { coefficient }\end{array}$ & t- count & t- table & probabilitas & $\begin{array}{c}\text { conclusion } \\
\text { t- count }>\text { t- } \\
\text { table) }\end{array}$ & Result \\
\hline H1.X1 $\rightarrow$ Y & 0.23001 & 3.113 & 1.964 & 0.0020 & significant & $\begin{array}{c}\text { H1 } \\
\text { accepted }\end{array}$ \\
\hline H2.X2 $\rightarrow$ Y & 0.0084 & 0.116 & 1.964 & 0.9075 & insignificant & H2 rejected \\
\hline H3.X3 $\rightarrow$ Y & 0.3198 & -1.546 & 1.964 & 0.1229 & insignificant & H3 rejected \\
\hline H4.X4 $\rightarrow$ Y & 0.1396 & 4.136 & 1.964 & 0.0000 & significant & H4 \\
\hline
\end{tabular}

Source: based on the regression analysis output in this study

Furthermore, based on table 4.1 can be explained as follows:

1. Hypothesis testing partially by t test, obtained the results of the $t$ count for the variable $\mathrm{X} 1$ of 3.113 with $\mathrm{p}$ value of 0.0020 is stated significant, and the value of $t$ arithmetic for the variable $\mathrm{X} 4$ of 4.136 with $\mathrm{p}$ value of 0.0000 expressed significant effect on Y because the value of t-count $>$ t-table (obtained t table $=1.964$ at alpha $5 \%$ with $\mathrm{df}=\mathrm{n}-2=660-2=658$ ). The $\mathrm{p}$ value of the three variables is also smaller than 0.05 so that it is stated to have a significant effect on Y. This indicates that the $\mathrm{H} 1$ hypothesis, and $\mathrm{H} 4$ are accepted.

2. While the value of $t$ arithmetic for the variable $X 2$ is 0.116 , with $p$ value of 0.9075 is declared not significant, because because t count is smaller than t table $=1.964 \mathrm{t}$ table at alpha $5 \%$ and $\mathrm{df}=\mathrm{n}-2=1132-2=1130$ ) and the calculated $\mathrm{t}$ value for the $\mathrm{X} 3$ variable is -1.546 with a value of $\mathrm{p}$ value of 0.1229 also not significant, because because $\mathrm{t}$-count is smaller than $\mathrm{t}$ table $=1.964$. So the independent variables $\mathrm{X} 2$ and $\mathrm{X} 3$ partially / individually do not affect the dependent variable Y. This shows that the hypothesis $\mathrm{H} 2$ and $\mathrm{H} 3$ are rejected.

The results of testing hypotheses that explain the effect of independent variables on the dependent variable, the following findings:

1. The first hypothesis: the value of $t$-countdividend policy variable is 3.113 with $\mathrm{p}$ value 0.0020 is declared significant, then the first hypothesis dividend policy affects the firm value can be accepted. This means that with a $95 \%$ confidence level, it can be concluded that dividend policy affects the firm value. Dividend policy has a statistically significant positive effect of 0.230 on the firmvalue. This means statistically that if the dividend policy increases by $5 \%$, then the firmvalue will increase by $0.230 \%$. The meaning of the results of this test is that the prices for the observed shares will increase if the dividend policy rises, because the stock price is a proxy of the firm value. The findings of positive and significant signs of the dividend policy indicate that manufacturing companies sector in Indonesia are sensitive to dividend payments, because the investor holding a stock in accordance with Bird In Hand Theory (Gordon, MJ, 1963), states that investors prefer dividends, because they are more certain than capital gain. The results of this study support the results of 
previous research conducted by Yudana, I.K., and Wati, NWAE., (2011), managerial ownership has a significant positive effect on firm value, dividend policy has a significant positive effect on firm value; and Rizqia, et al., (2013), dividend policy has a positive effect on the firm value. But in contrast to the results of previous studies conducted by Hardiningsih, (2009), variable dividend policy does not have a positive and insignificant effect on the firm value.

2. The second hypothesis: The value of t-count for Managerial Ownership variable is 0.116 with a $\mathrm{p}$ value of 0.9075 is also stated to have insignificant effect on $\mathrm{Y}$, because because t-count is smaller than $\mathrm{t}$ table $=1.964$, then the second hypothesis stating that Ownership Managerial influence on Company Value is unacceptable. This means that with a 95\% confidence level, it can be concluded that Managerial Ownership have insignificant effect on firm Value. Managerial ownership has a negative effect but insignificant on the firm value. This finding shows that it is not in accordance with the statement that the higher the ownership of insiders, the higher the value of the company Jensen, M.C., (1993). The results of this study support the results of previous studies conducted by Hardiningsih, (2009), and different research by Sukirni, D., (2012), managerial ownership has a significant negative effect on firm value. But in contrast to the results of previous research conducted by Taswan and Soliha, E., (2002) and Rizqia, et al., (2013), Managerial Ownership has a positive effect on the firm value.

3. The third hypothesis: the $t$-count for the board size variable is -1.546 with $p$ value of 0.1229 is stated to have insignificant effect on $\mathrm{Y}$, because because $\mathrm{t}$-count is smaller than $\mathrm{t}$-table $=1.964$, then the second hypothesis stating that the board size has an unacceptable effect on the firm Value. This means that with a 95\% confidence level it can be concluded that the Board Size does not have an influence on the firm value. This finding is not in accordance with the statement that the higher the board size, the higher the firm value. This finding does not support the results of research by Mai, M.U., (2011), the board size has a positive and significant effect on Tobin's q. But supporting the results of previous research conducted by Yermack, D., (1996), concluded that the small-scale the board size would be more effective in carrying out supervisory actions than large-sized the board size.

4. The fourth hypothesis: the t-count for the profitability variable is 4.136 with a $p$ value of 0.0000 expressed as significant, then the fourth hypothesis stating that profitability has an effect on the firmvalue is acceptable. This means that with a $95 \%$ confidence level, it can be concluded that profitability affects the firm value. Profitability has a statistically significant positive effect of 0.139 on the firmvalue. This means statistically that if the profitability increases by $5 \%$, then the firm value will increase by $0.139 \%$. This finding supports the research by Rizqia, et al., (2013), profitability has a positive effect on firm value. But in contrast to research by Haryuningputri, M. and Widyarti, ET., (2012), ROA has insignificant effect on stock prices.

So, the two independent variables used are dividend policy and profitability is stated to significantly affect the firm value, while managerial ownership and board size insignificantly affect the firm value, so the independent variables managerial ownership and board size do not partially affect the dependent variable of firm value. This shows that the firm value of manufacturing companies sector in Indonesia is more determined by dividend policies and profit, but not by the incentives of managers and monitoring of 
the board to managers, because in general the managers and the board are held by the majority shareholders.

\section{Contribution of Research Results}

The results of this study have implications for the agency theory, according to Jensen, M. and Meckling, W. (1976), that managers as agents of shareholders (principals) do not always act on behalf of the principal's interests, because the welfare of shareholders depends on the firm value, while the manager welfare depends on size and profit. To force the managers to incentivize and monitor the managers, so that their actions maximize the principal's interests. The findings of this study prove that the firm value of manufacturing sector in Indonesia is more determined by dividend policies and profit, but not by incentives of the managers and monitoring of the board, because generally the managers and the board of manufacturing sector in Indonesia are held directly by the majority shareholders. As well as proving the dividend theory of Jensen, M. and Meckling, W. (1976), that the increase in the ratio of dividend payments to reduce agency costs, because dividend payments reduce the funds available to the managers, and force the managers to look for external sources to finance the investment. This reduces agency problems which ultimately can increase the firm value.

\section{CONCLUSION}

Based on the findings and discussion, it can be concluded that: a) Dividend payments motivate the investors of manufacturing sector to buy stock of firm that pay dividends, because the investors are more interested in firm that pay high dividends; b) Managerial ownership and the board size are effective and able to balance the strength of the manager and shareholders; and c) Profitability is able to be a positive information signal for its investment, therefore, when a company achieves high return, investors will be captured on the IDX as a positive signal of a high future dividend yield.

\section{REFERENCES}

Beiner, S., et.al., (2003), An integrated framework of corporate governance and firm valuation: Evidence from Switzerland, ECGI Working Paper Series in Finance (www.ecgi.org/Wp)

Christiawan, Y.J., dan Tarigan, J., (2007), Kepemilikan Manajerial, Kebijakan Hutang, Kinerja dan Nilai Perusahaan, Jurnal Akuntansi dan Keuangan Vol. 9. No. 1 Mei 2017.

Fama, E. F, (1978), The Effect of Firm's Invesment and Financiang Decision on the Welfare of is Security Holders, American Economic Review 68: 272-288.

Gordon, M.J. (1963), Optimal Invesment and Financing Policy, Journal of Finance, pp. 264-272

Hardiningsih, P., (2009),Determinan Nilai Perusahaan, JAI Vol.5 , No.2, Juli 2009 : 231-250

Haryuningputri, M. dan Widyarti, ET., (2012), Pengaruh Rasio Profitabilitas Dan EVA Terhadap Harga Saham Pada Sektor Industri Manufaktur Di BEI Tahun 20072010, Volume 1, Nomor 2, Tahun 2012, Halaman 67-79 http://ejournals1.undip.ac.id/index.php/djom 
Hasnawati, S., (2005), Pengaruh Keputusan Investasi, Keputusan Pendanaan, danKebijakan Deviden Terhadap Nilai Perusahaan Publik (Di Bursa Efek Jakarta), Disertasi tidak dipublikasikan, Universitas Padjadjaran Bandung.

Jensen, M. dan Meckling, W. (1976), Theory of the Firm: Managerial Behavior, Agency, and Ownership Structure, Journal of Financial Economics, Vol. 4, No.4 (October): pp. 305-360.

Jensen, M.C., (1986), Agency Costs of Free Cash Flow, Corporate Finance, and Take overs, American Economic Review, Vol. 76: pp. 23-329.

Jensen, M.C., (1993), The Modern Industrial Revolution, Exit, and the Failure of Internal Control System, Journal of Finance, Vol. 48. (July): pp. 831-880.

Komite Nasional Kebijakan Governance, KNKG (2006), Pedoman Umum Good Corporate Governance Indonesia, Roadmap Tata Kelola Perusahaan Indonesia, OJK

Mai, M.U., (2011), Pengaruh Mekanisme Corporate Governance Terhadap Nilai Perusahaan Dan Mediasi Kebijakan Dividen, Jurnal Ekonomi dan Bisnis, Vol 10, No. 1, Juni 2011

Rizqia, dkk., (2013), Effect of Managerial Ownership, Financial Leverage, Profitability,Firm Size, and Investment Opportunity on Dividend Policy and Firm Value, Research Journal of Finance and Accounting www.iiste.org ISSN 2222-1697 (Paper) ISSN 2222-2847 (Online), Vol.4, No.11, 2013

Sartono, R.A., (2000), Manajemen Keuangan: Teori dan Aplikasi, Edisi Ketiga Yogyakarta: BPFE Yogyakarta.

Smith, M., dan Skousen, K., (1992), Akuntansi Intermediate: Volume Komprehensif, Jilid 2, alih bahasa Nugroho Wijayanto.

Suad, H., (2008), Manajemen Keuangan Teori dan Penerapan (Keputusan Jangka Panjang), Yogyakarta : BPFE.

Sukirni, D., (2012), Kepemilikan Manajerial, Kepemilikan Institusional, Kebijakan Dividen, dan Kebijakan Utang Analisis terhadap Nilai Perusahaan, Accounting Analysis Journal, Vol. 1, No. 2, pp. 1-12.

Taswan dan Soliha, E., (2002), Pengaruh Kerbijakan Utang Terhadap Nilai Perusahaan Serta Beberapa Factor Yang Mempengaruhinya, Jurnal Bisnis dan Ekonomi, 7(1): 1-10.

Website ICMD, http://www.idx.co.id, Jakarta, Indonesia, 2010-2017

Weston, F.J., dan Copeland, T.E., (1995), Manajemen Keuangan, Edisi Kedelapan Jilid I, Erlangga: Jakarta.

Wright, P., dan Ferris, S.P., (1997), Agency Conflict \& Corporate Stategy: The Effect of Divestment on Corporate Value, Strategic Management Journal, Vol. 18: pp. 7783.

Yermack, D., (1996), Higher Market Valuation of Companies with a Small Board of Directors, Journal of Financial Economics. Vol.40 :185-211

Yudana, I.K., dan Wati, NWAE., (2011), Struktur Kepemilikan, Kebijakan Dividend dan Nilai Perusahaan, perusahaan Manufaktur Yang Go Public, Jurnal Keuangan dan Perbankan, Vol 5, No. 1 Januari 2011, hlm. 58-65 